\title{
Article \\ Degradation of welded joint made of T91 steel with different additional materials
}

\author{
Kwiryn Wojsyk ${ }^{1}$, Klaudia Klimaszewska ${ }^{1,}{ }^{*}$, Grzegorz Golański ${ }^{1}$ \\ ${ }^{1}$ Czestochowa University of Technology, Poland \\ dr inż. Kwiryn Wojsyk; kwiryn@gmail.com; \\ dr hab. inż. Grzegorz Golański, prof. PCz; grisza@wip.pcz.pl; \\ * Correspondence: mgr inż. Klaudia Klimaszewska; klimaszewska.klaudia@outlook.com
}

Received: 22.03.2019; Accepted: 08.06.2019

\begin{abstract}
The aim of the research was to analyse the processes of degradation observed in a similar welded joint of T91 steel. The analysis was performed for welded joints after long-term annealing for up to 8000 hours at the temperature of $600{ }^{\circ} \mathrm{C}$. Microstructural analysis and hardness testing were performed. The purpose of the tests was to evaluate the effect of annealing time at the temperature of ageing on formation and properties of the decarburized zone in the inter-bead area of the welded joint. The study presents the results of physical examinations of the joint welded using two different filler materials (similar welded joint) after long-term effect of high temperature.
\end{abstract}

Keywords: low alloy filler material; homogeneous joint; ageing; T91 steel

\section{Introduction}

A topical and important problem in the energy system is to design and implement materials for installations operating under conditions of high thermomechanical load. Their implementation offers opportunities for achievement of increasingly high parameters of vapour and consequently, reaching a substantial efficiency and reduction of emissions of greenhouse gases by energy equipment [1,2]. The pivotal points of such structures are welded joints, whose properties should be similar to properties of base material. However, in many cases, technological reasons lead to the attempts to use the solutions that simplify

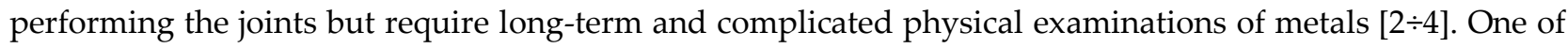
such solutions is performing a root run with easily-weldable filler material that ensures plastic, deformable first layer of the joint. The above solution does not require an expensive shield gas (pure argon) that fills the pipe joints in their interior part, leading to substantial savings. Thus method has already been applied for welding hardly-weldable materials not used in the energy sector $[5,6]$. There are no studies concerning this type of composite joints and evaluation of their functional usefulness under conditions of thermal load.

\section{Materials and Methods}

The research material was butt joints performed on the pipe made of martensitic X10CrMoVNb9-1 (T91) steel with diameter of $76 \mathrm{~mm}$ and wall thickness of $10 \mathrm{~mm}$. These joints were made using the 141 (TIG) method in the H-L045 position using two filler materials:

- Böhler W CrMo2Si ø2.4 mm - first run (root),

- Böhler W CrMo91 ø2.4 mm - filling run and final run.

Welding parameters are presented in table I. The shield for the weld pool was provided by the inert gas (argon). Thermal processing was used after welding, consisting of annealing at the temperature of $760^{\circ} \mathrm{C}$ for 2 $\mathrm{h}$ followed by cooling down in air (initial state). Analysis of the chemical composition of the base material (T91 steel, Fig. 2) was performed using SpectroLab K2 spark spectrometer. The required chemical composition of filler materials used for welding the backing bead and filling layers is presented in tables III and IV [7]. The obtained welded joints were subjected to both non-destructive and destructive examinations. The non-destructive examinations were performed for 100\% length of the joints and included visual testing, magnetic testing (MT) and radiographic testing (RT). The planned destructive examinations included macroand microscopic observations and microhardness tests. Microstructural observations were performed using the Olympus GX41 optical microscope and JSM JEOL-6610 scanning electron microscope (SEM). Metallographic wastes were etched with nital. Microstructural measurements were performed using a 
microhardness tester (Shimadzu HMV-G20) at the load of $0.1 \mathrm{kG}(0.981 \mathrm{~N})$. All the examinations of mechanical properties were performed according to PN-EN ISO 17639 and [7].

The examinations concerned the joint in the initial state and after ageing at the temperature of $600{ }^{\circ} \mathrm{C}$ for $8000 \mathrm{~h}$. The aim of the examinations was to observe potential changes in joint morphology. The particular focus was on the evaluation of the effect of ageing on the size and structure of the decarburized zone under conditions similar to functional thermal load.

Table I. Welding parameters of the examined joint

\begin{tabular}{|c|c|c|c|c|c|c|c|}
\hline \multicolumn{8}{|c|}{ Details of welding } \\
\hline Bead & $\begin{array}{l}\text { Welding } \\
\text { method }\end{array}$ & $\begin{array}{c}\text { Filler metal } \\
\text { dimensions } \\
{[\mathrm{mm}]}\end{array}$ & $\begin{array}{c}\text { Current } \\
\text { intensity } \\
\text { [A] }\end{array}$ & $\begin{array}{c}\text { Arc } \\
\text { voltage } \\
\text { [V] }\end{array}$ & $\begin{array}{c}\text { Current type/ } \\
\text { polarity }\end{array}$ & $\begin{array}{l}\text { Feed rate } \\
{[\mathrm{cm} / \mathrm{min}]}\end{array}$ & $\begin{array}{c}\text { Amount of heat } \\
\text { transferred } \\
{[\mathrm{kJ} / \mathrm{mm}]}\end{array}$ \\
\hline 1 & 141 & ø 2.4 & 100 & 11.6 & DC/- & 6.2 & 0.67 \\
\hline 2 & 141 & $\varnothing 2.4$ & 92 & 12.6 & DC/- & 5.6 & 0.74 \\
\hline 3 & 141 & $\varnothing 2.4$ & 90 & 12.8 & DC/- & 4.2 & 0.98 \\
\hline 4 & 141 & $\varnothing 2.4$ & 90 & 12.9 & DC/- & 3.4 & 1.22 \\
\hline
\end{tabular}

\section{Results}

\section{Macroscopic examinations}

The macrostructure of the welded joints is presented in figure 1. The macroscopic examinations revealed a correct geometry of the joint, regular welded bead and narrow, even heat affected zone. Results of non-destructive examinations such as VT, PT, RT and macrostructural observation, revealed no significant welding defects on the cross-sections of welded joints that would exceed the level of quality B according to PN-EN ISO 5817. Darker areas in transition zones are more etched decarburized zones (Fig. 1b).

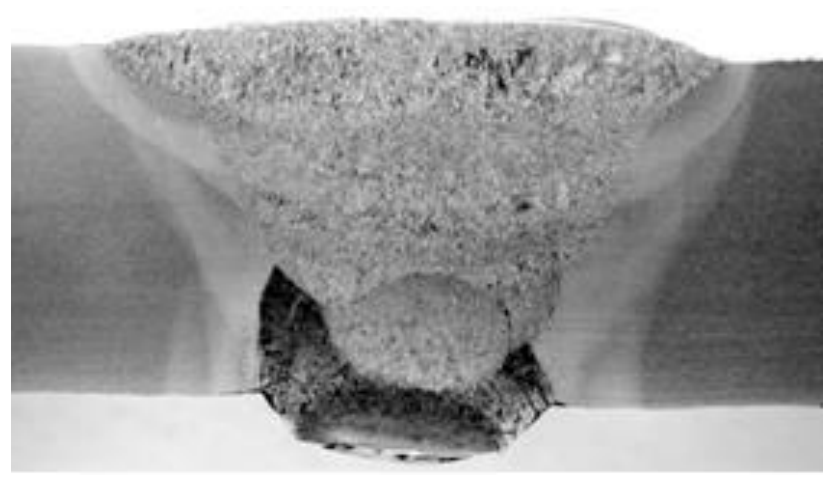

(a)

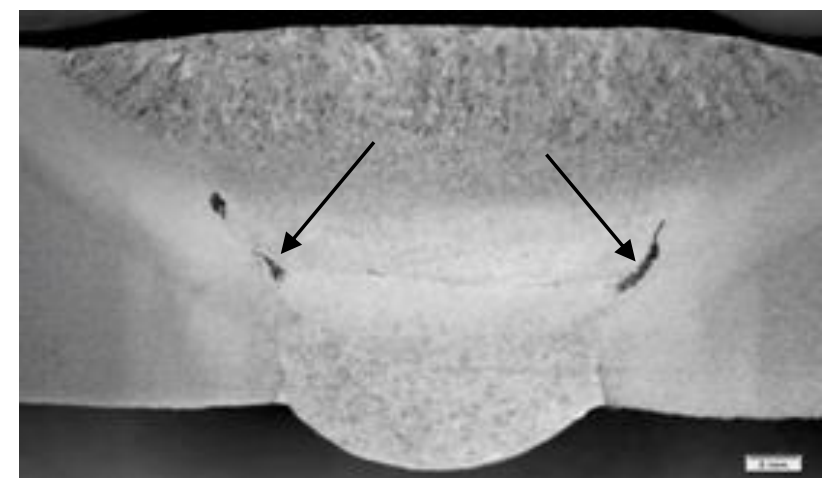

(b)

Fig. 1. Macrostructure of the welded joints: a) in the initial state, b) after ageing at $600{ }^{\circ} \mathrm{C} / 8000 \mathrm{~h}$

\section{Microstructural examinations, measurement of microhardness}

Microscopic observations of the weld material showed that this area was characterized by bainitic (bainite-martensite) structure in the root run (Fig. 2) and martensitic structure in the filling run (Fig. 3). The structures obtained in the weld result from the use of two filling materials that differ significantly in their chemical composition (Table II, Table III). With the varied chemical composition in the place of connection, the structural homogeneity occurs near the fusion line after thermal processing following welding and during long-term annealing. Structural non-homogeneity that is observed in the area of the welded joint is connected with diffusion of carbon from the area with higher chemical activity to those with lower activity. Carbide forming elements, such as chromium and molybdenum, substantially reduce chemical activity of carbon and lead to its diffusion towards high-alloy steel. This leads, on the one hand, to appearance of decarburized zone at the side of material with higher carbon potential and, on the other hand, the carburized zone on the side of the material with lower carbon potential. In the examined joint (initial state), this area included individual blocks of ferrite grains near the fusion lines around the root run. The structure of decarburized zone (Fig. 4) is characterized by coarse ferritic grains with individual carbides. The size of the zone with ferritic structure that occurs between the root run and the first filling run was ca. $775 \mu \mathrm{m}$ and width 
of

ca. $75 \mu \mathrm{m}$ (Fig. 5a). The area of fusion line also contained individual ferrite grains (Fig. 5b).

Table II. Chemical composition of T91 steel, \%mass

\begin{tabular}{ccccccccc}
\hline $\mathbf{C}$ & $\mathbf{S i}$ & $\mathbf{M n}$ & $\mathbf{P}$ & $\mathbf{S}$ & $\mathbf{C r}$ & $\mathbf{M o}$ & $\mathbf{V}$ & $\mathbf{N b}$ \\
\hline 0.09 & 0.37 & 0.47 & 0.01 & 0.003 & 8.83 & 0.95 & 0.19 & 0.08 \\
\hline
\end{tabular}

Table III. Chemical composition of Böhler W CrMo2Si filler material according to PN-EN ISO 6507-1, \%mass

\begin{tabular}{ccccccccc}
\hline $\mathbf{C}$ & Si & Mn & Cr & Mo & P & As & Sb & Sn \\
\hline 0.06 & 0.72 & 0.95 & 2.61 & 1.02 & .0 .01 & 0.01 & 0.005 & 0.006
\end{tabular}

Table IV. Chemical composition of Böhler W CrMo91 filler material according to PN-EN ISO 6507-1, \%mass

\begin{tabular}{cccccccc}
\hline $\mathbf{C}$ & $\mathbf{S i}$ & $\mathbf{M n}$ & $\mathbf{C r}$ & $\mathbf{N i}$ & $\mathbf{M o}$ & $\mathbf{V}$ & $\mathbf{N b}$ \\
\hline 0.12 & 0.31 & 0.52 & 9.00 & 0.71 & 0.92 & 0.20 & 0.055 \\
\hline
\end{tabular}
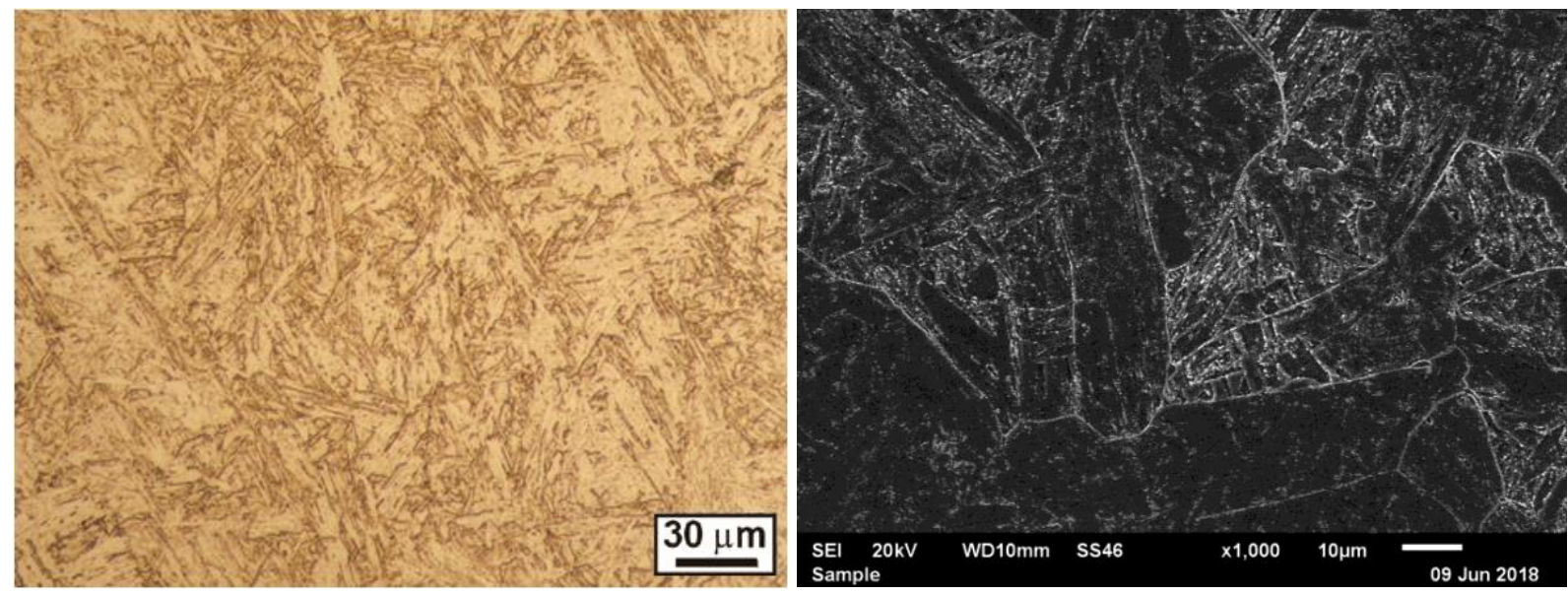

Fig. 2. Weld microstructure in the final run
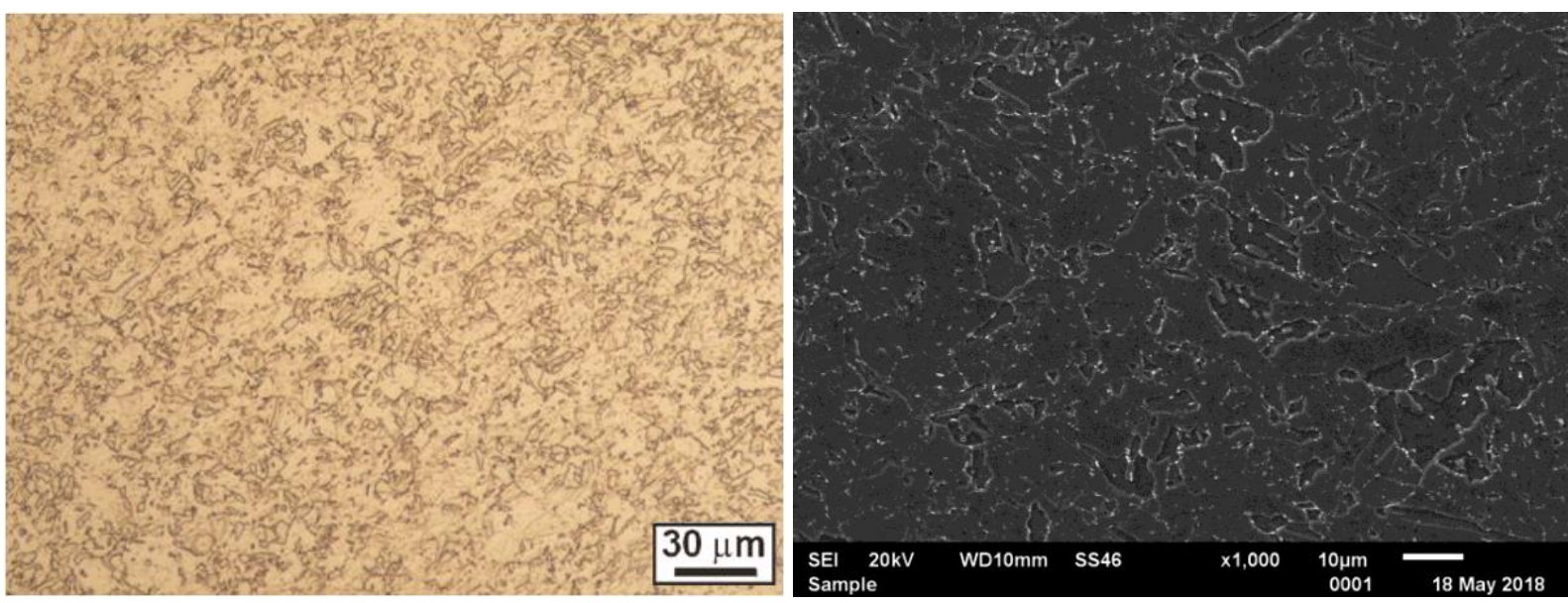

Fig. 3. Weld microstructure in the root run 

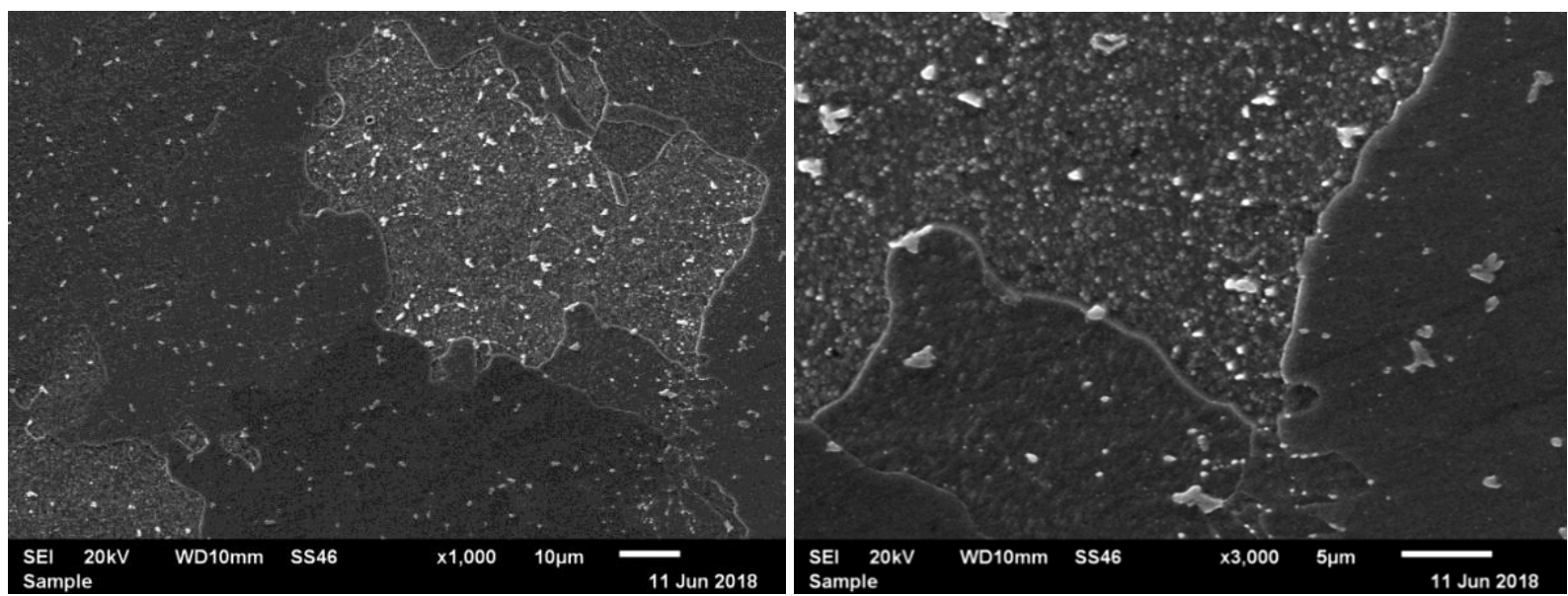

Fig. 4. Structure of the decarburized zone in the weld after ageing

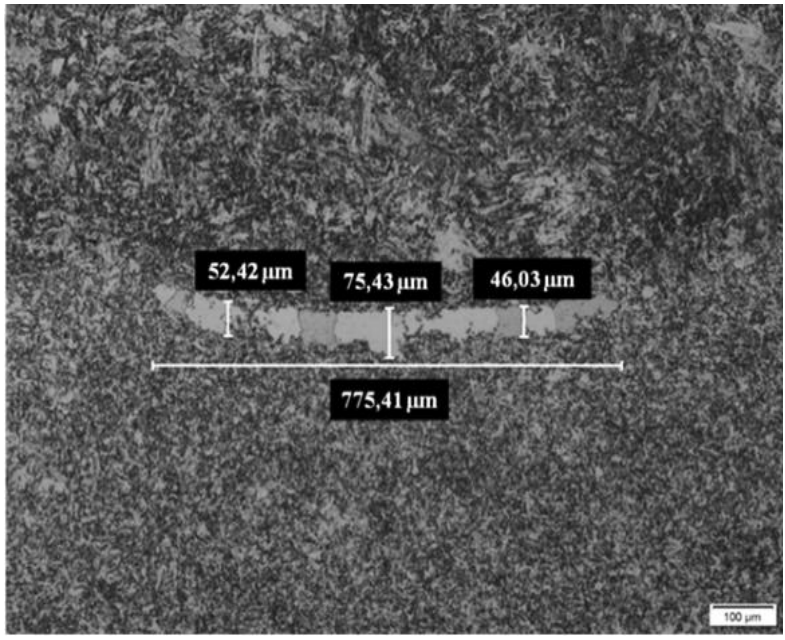

(a)

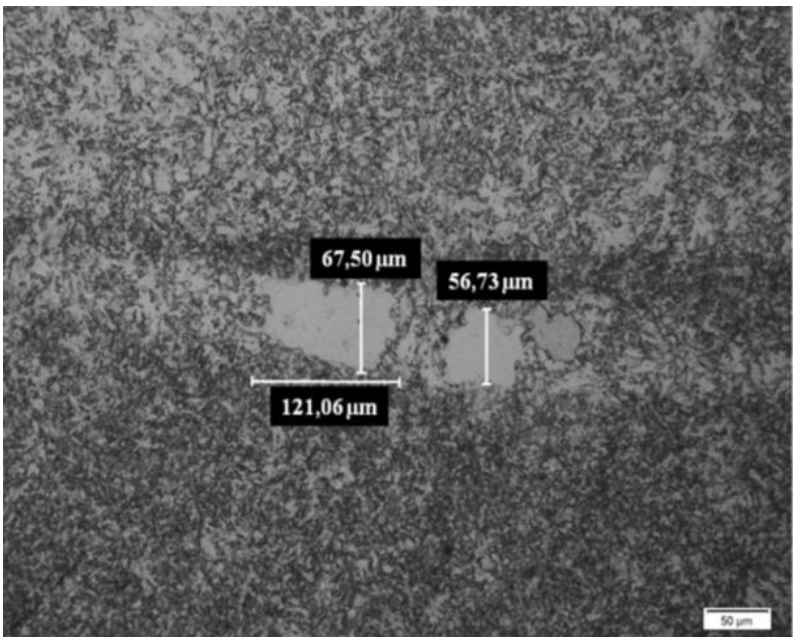

(b)

Fig. 5. Microstructure of the welded joint in the initial state in the area of the decarburized zone: a) between the first and second run, $b$ ) at the fusion line

Joint ageing contributed substantially to the increase in the magnitude of the decarburized zone between the filler material and root run and the growth of ferrite grains inside this zone. The magnitude of the area between the root run and the filling run after ageing was comparable with the initial state (Fig. 6).

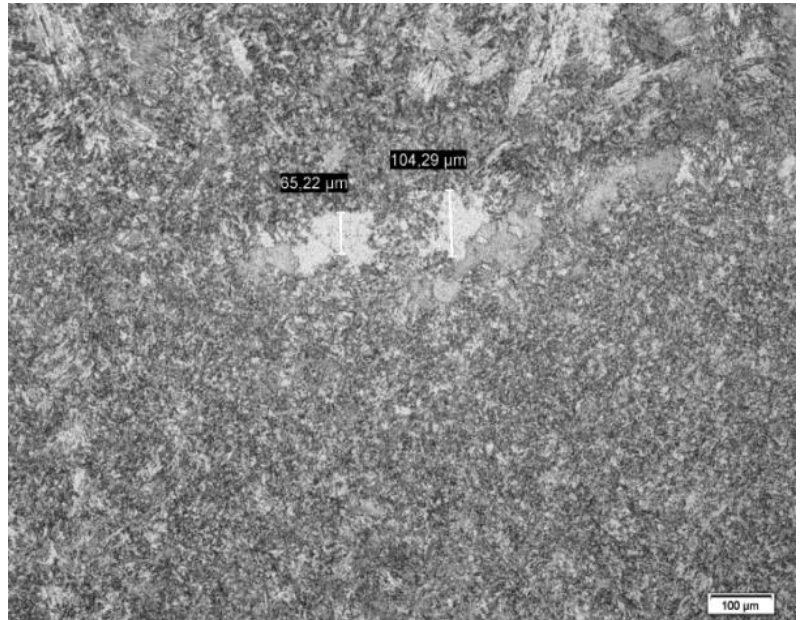

(a)

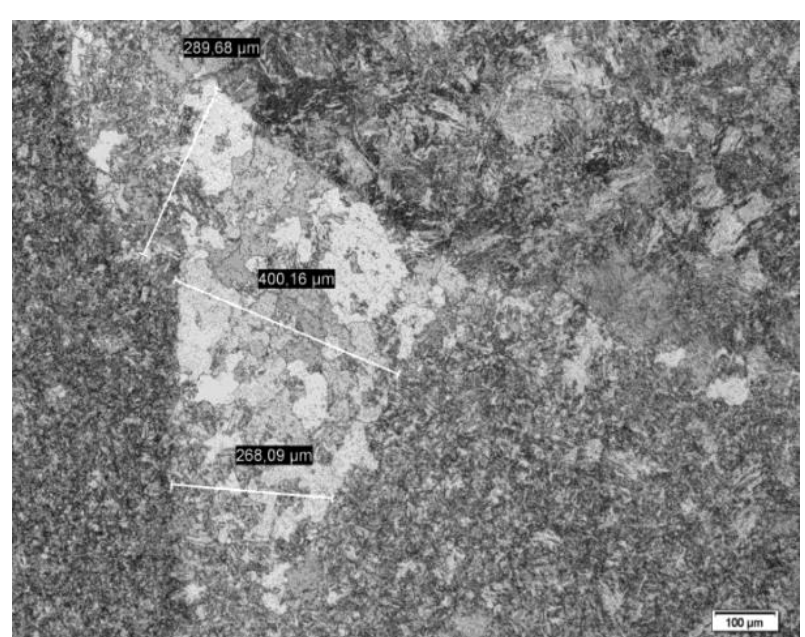

(b)

Fig. 6. Microstructure of the joint after welding and ageing $600{ }^{\circ} \mathrm{C} / 8000 \mathrm{~h}$ in the area of the decarburized zone: a) between the first and second run, $b$ ) at the fusion line

According to [8,9], formation of the decarburized zone is also stimulated by the lack of nitrogen in the matrix in this area and phase work-hardening with critical size due to the exchange of austenite into 
martensite. Narrower carbon-rich zone is observed near the decarburized zone (darker area in Fig. 4 and Fig. 5 near the ferrite grains). It is characterized by elevated amount of carbides, mainly chromium-rich carbides

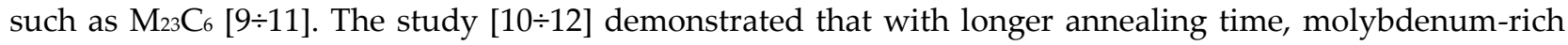
carbides $\left(\mathrm{M}_{2} \mathrm{C}\right.$ and $\left.\mathrm{M}_{6} \mathrm{C}\right)$ are observed in addition to $\mathrm{M}_{23} \mathrm{C}_{6}$ with longer times of annealing near this zone.

With the coarse-grain ferritic structure, lack of carbides and less carbon and/or nitrogen in the matrix, the decarburized zone is characterized by lower mechanical values e.g. hardness (microhardness). Microhardness testing in the examined zone revealed its significant reduction compared to the joint (Fig. 7). This reduction was from 70 to $100 \mathrm{HV} 0.1$ in the joint in the initial state and $60 \div 110 \mathrm{HV} 0.1$ in the joint after annealing. According to [11,12], formation and growth of the decarburized zone is conducive to higher tendencies for type III cracking, whereas according to [10,12], it also impacts on joint susceptibility to type IV cracking.

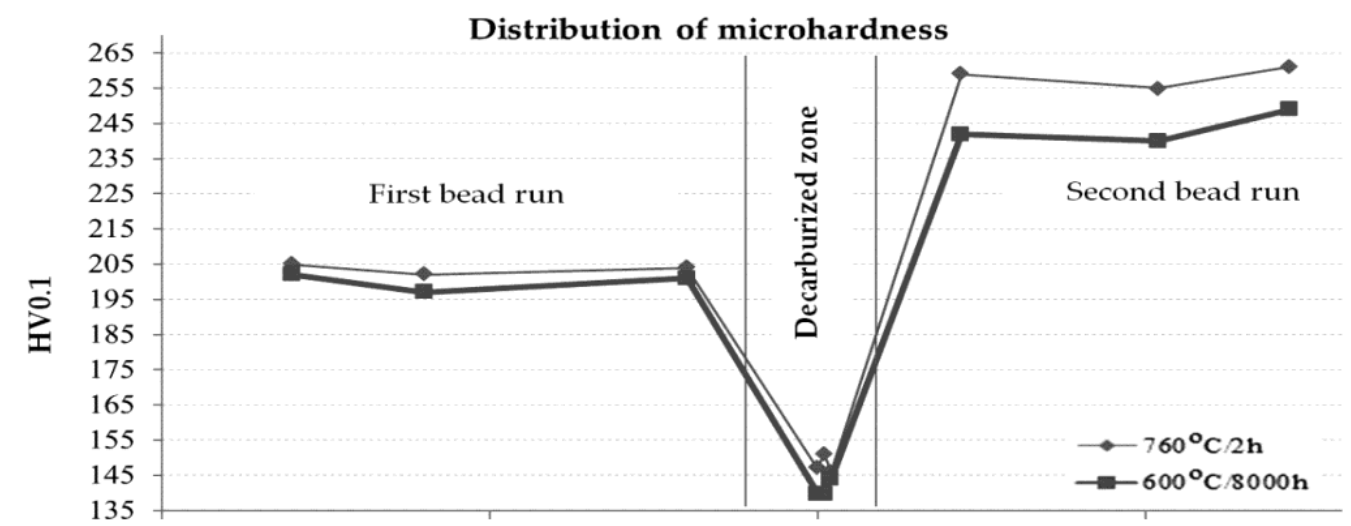

Fig. 7. Distribution of microhardness in the area of decarburized zone

\section{Discussion}

The examinations of the welded joints made of T91 steel containing the low-alloy root revealed changes at the boundary between the root run with base material and high-alloy part of the weld. The examinations were performed directly following welding (joint in the initial state) and after 8,000 $\mathrm{h}$ at the temperature of $600{ }^{\circ} \mathrm{C}$, but they offer the insight into the type and degree of changes after longer periods of heat load to such types of joints. The particularly alarming is growth of grain in the soft ferrite welding zone and presence of carbides of various types. This process is not, however, directly connected with the growth of the width of the decarburized zone in the examined period of time. Further research is needed into the effect of presence of decarburized ferritic zone in a small internal part of the joint on its functional usefulness during long-term thermal and mechanical loads.

Conflicts of Interest: The authors declare no conflict of interest.

\section{References}

[1] Sorentino S., Welding technologies for ultra-supercritical power plant materials, Materials for Ultra-Supercritical and Advanced Ultra-Supercritical Power Plants, Woodhead Publishing, 2017, 274-316. [CrossRef]

[2] Zieliński A., Dobrzański J., Purzyńska H., Sikora R., Dziuba-Kałuża M., Kania Z., Evaluation of creep strength of heterogeneous welded joint in HR6W alloy and Sanicro 25 steel, Archives of Metallurgy and Materials, 2017, Vol. 62(4), 2057-2064. [CrossRef]

[3] Łomozik M., Zeman M., Jachym R., Cracking of welded joints made of steel X10CrMoVNb9-1 (T91) - case study, Metallic Materials, 2012, Vol. 50(4), 285-294. [CrossRef]

[4] Zieliński A., Dobrzański J., Purzyńska H., Golański G., Structure and creep resistance of austenitic steel Super 304H, Materials Testing, Properties, Vol. 57(10), 859-865. [CrossRef]

[5] Czupryński A., Kik T., Górka J., Using of low heat input CBT process in joning of high-alloy steel with cooper, Welding Technology Review, 2015, Vol. 87(5), 23-33. [CrossRef]

[6] Wojdat T., Kustroń P., Lange A., Łącka I., Research on the properties braze-welded joints aluminium with steel using filler metals on Al and Zn matrix, Welding Technology Review, 2017, Vol. 89(7), 22-25. [CrossRef]

[7] High Temperature and Creep-resistant Filler Metals - BÖHLER

[8] Foret R., Zlamal B., Sopouse J., Structural stability of dissimilar weld between two Cr-Mo-V steels, Welding Journal, 2001, Vol. 6(6), 405-411. [CrossRef] 
[9] Dawson K.E., Tatlock G.J., Chi K., Barnard P., Changes in precipitate distributions and the microstructural evolution of P24/P91 dissimilar metal welds during PWHT, Metallurgical and Materials Transactions A, 2013, Vol. 44(11), 5065-5080. [CrossRef]

[10] Sudha C., Paul V.T., Terrance A.L.E., Saroja S., Vijayalakshmi M., Microstructure and microchemistry of hard zone in dissimilar weldments of Cr-Mo steels, Welding Research, 2006, Vol. 6(85), 71-80. [CrossRef]

[11] Sudha C., Terrance A.L.E., Albert S.K., Vijayalakshmi M., Systematic study of formation of soft and hard zones in the dissimilar weldments of Cr-Mo steels, Journal of Nuclear Materials, 2002, Vol. 302(2-3), 193-205. [CrossRef]

[12] Tasak E., Ziewiec A., Brzeziak A., The problems appearing during the reparation of welds in dissimilar steels, Archives of Foundry, 2006, Vol. 6(21/2), 221-227.

(C) 2019 by the authors. Submitted for possible open access publication under the terms and conditions of the Creative Commons Attribution (CC BY) license (http://creativecommons.org/licenses/by/4.0/). 